\title{
61 。ニューロトラック（腷波解析モニタ）
}

の手術窒における使用経験

東京大学中央手術部

釘宮豊城 都築正和

東京大学麻酔科

阿久根透稻田豊

全身麻酥中に䏚波がモニタされてい ない理由として、

1 。脳波計の物理的な大きさによる手 術室搬入の制限

2 。腷波計の取り扱い, 判断。分析の 難かしさ

3。手術中の体位，体動などによる腷 波計の装着条件の恶さ

4 。電気メスの使用。手術操作等によ る笔気的ノイズの混入流よ゙が考えら れる

これらの従来の腷波計に関する諸問 題を解決したコンパクト2チャンネル 腷波モニタ，二ューロトラックを使用 する機会を得られたので、臨床の場で の使用勝手とその結果について症例を あげて報告する。

\section{(症例 1 )}

62 扌女性、左内澒動脈㿇

手術中に一側の内頝動脈を遮断しな ければならない出例で、遮断トライア ル3分間で、腷波上に变化のないこと を確認した後に手術を決行した。無事 手術も終了し、麻酔の覚醒も良好であ つた。这波モニタがなければ、術式も 動脈㒛ラッピング等に变更しなければ ならない症例であった。

\section{(症 例 2 )}

73 才男性、胸部大動脈瘤

動脈瘵が両側の頝動脈に及んでいる ために45分間にわたって低体温下に
㧍いての全循環遮断を行い、グラフト 移殖術を行なった症例で、麻酕は大量 フエンタニール麻酔で行なった。大量 フエンタニール麻酔は、かなり深い麻 酔で全身状態は安定して心臓の瞅酔な どでは多用されているが、瑟日まで覚 醒しない事が多い。術中に脑波をモ二 タすることにより、低体温により媨が 保護されていたかが術中に知ることが できて有用であった。

\section{(症例 3 )}

26才男性、閉鎖循環式麻酔

閉鎖循環式麻酔は、麻酔ガスの流量 が少なく、手術室内麻醉ガス污染が低 く、また患者の換気量、酸素消費量等 得られる情報も多いなどの利点もある が、反面、全笑気の時期があったり、 酸素も代謝に必要な量しか与えないな ど腷への酸素供給上で心配な点がある 媨波を連続的にモニタすることによ り、麻酔深度、中枢神経機能の变化を 知ることができ、より安全な麻暂とな った。 
医器学 Vol. 55, Suppl. (1985)

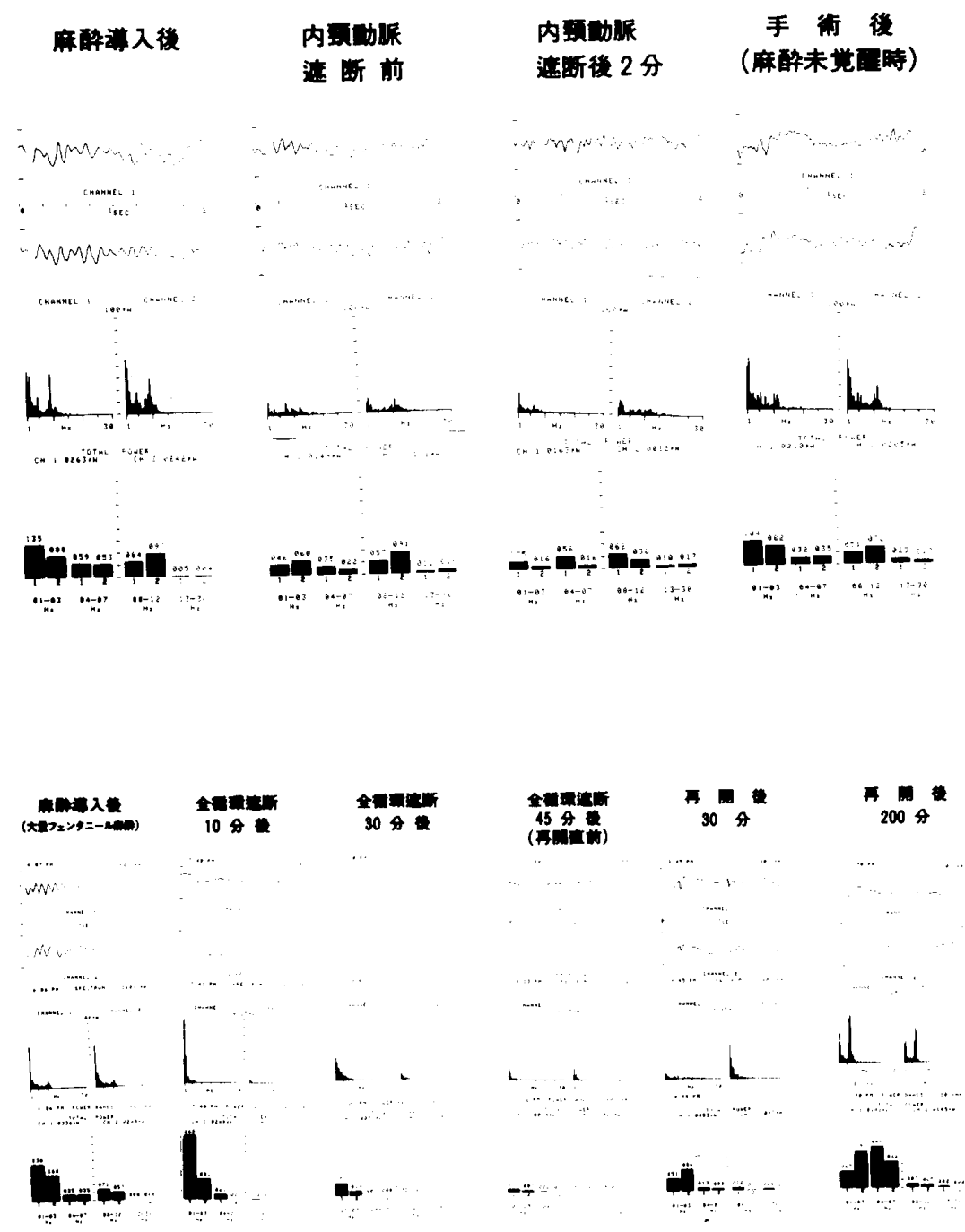

（症例 1 ）

(症 例 2 )

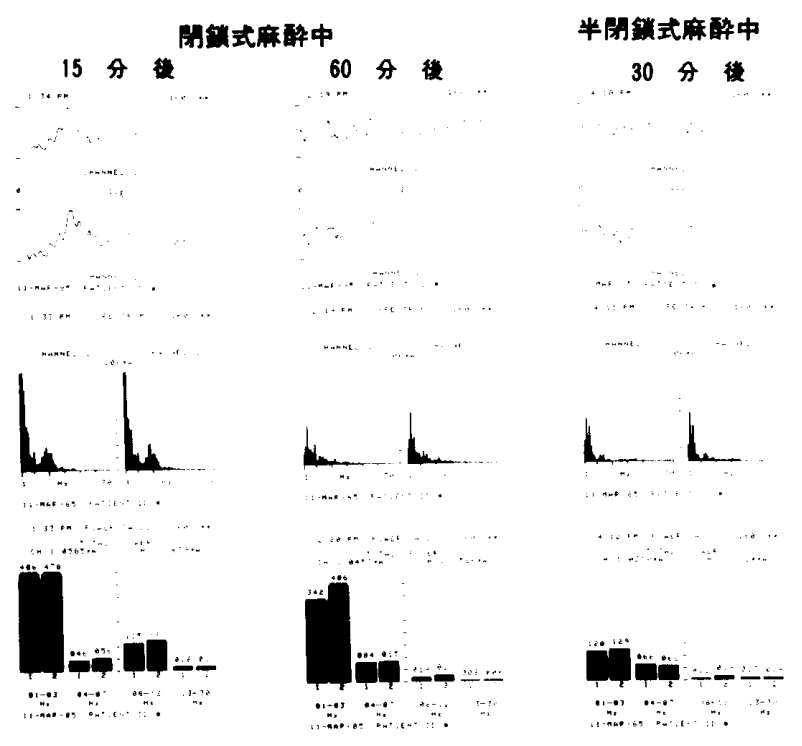

(症例 3 ) 